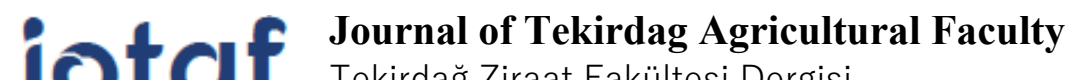 \\ Tekirdağ Ziraat Fakültesi Dergisi
}

\section{Investigating The GMO Existence in Chips and Breakfast Cereals Marketed in Turkey}

Türkiye'de Satılan Cips ve Gevreklerde GDO Varlığının Araştırılması

\author{
Sebnem MUTLU1 ${ }^{1}$, Osman SIMSEK ${ }^{2}$, Omer OKSUZ ${ }^{2}$
}

\begin{abstract}
In this research, processed or low processed samples containing corn or corn products (corn semolina, flour, etc.) and soybean were randomly collected from the market, and 25 products in total (chips, nuts, cereals, flour) were analyzed for genetic modification using DNA based detection method, the polymerase chain reaction. First, homogenization of the samples was performed. Then DNA isolation was done by using Cetyl Trimethyl Ammonium Bromide (CTAB) and Roche High Pure DNA Isolation Kit. Since the Roche High Pure DNA Isolation Kit gave better results, the analysis was completed with this method. After DNA isolation, the detection of the Lectin gene, Zein gene, CaMV 35S Promoter and NOS Terminator regions was performed by conventional PCR. Zein gene determination was done for searching and proving corn presence and similarly, Lectin gene determination was done for searching and proving soybean presence in the samples by conventional PCR. GMO3/GMO4 and Zein3/Zein4 primer pairs were used for Lectin and Zein gene determination, respectively. The amplification of DNA was observed in agarose gel electrophoresis. Lectin or Zein genes were detected in 17 samples while these genes were not detected in 8 samples. Samples, in which Lectin or Zein gene was detected were scanned for $35 \mathrm{~S}$ promoter or NOS terminator. $35 \mathrm{~S}-3 / 35 \mathrm{~S}-6$ and tNOS2F/tNOS2R primer pairs were used for scanning 35S Promoter and NOS Terminator, respectively. To observe possible contamination in the mix sterilized deionized water was used and $0 \%$ Bt- 11 and $0 \%$ GTS 40-3-2 were used as a negative control, $5 \%$ Bt- 11 and 10\% GTS-40-3-2 were used as a positive control. All of the 25 samples did not provide enough DNA with the required quality. This result was considered to be sourced by the applications (frying, extruding, pressing etc.) that samples had been exposed to during processes. Neither 35S Promotor nor NOS Terminator was determined from any of the samples.
\end{abstract}

Keywords: GMO, Convantional PCR, Lectin, Zein, 35S Promotor, NOS Terminator

\footnotetext{
1*Sorumlu Yazar/Corresponding Author: Sebnem Mutlu, Edirne Food Control Laboratory Directorate, Edirne, Turkey. E-mail: sebnem.olucay@tarimorman.gov.tr (iD) OrcID: 0000-0002-2057-9991

${ }^{2}$ Osman Simsek, Department of Food Engineering, Namık Kemal University, Tekirdağ, Turkey. E-mail: osimsek@nku.edu.tr (D) OrcID: 0000-0001-8506-0202. ${ }^{3}$ Omer Oksuz, Department of Food Engineering, Namık Kemal University, Tekirdağ, Turkey. E-mail: ooksuz@nku.edu.tr (D) OrcID: 0000-0002-3223-3154. Atıf/Citation: MUTLU S., SIMSEK O., OKSUZ O. Investigating The GMO Existence in Chips and Breakfast Cereals Marketed in Turkey. Tekirdağ Ziraat Fakültesi Dergisi, 18 (3), 375-385.

*Bu çalışma Yüksek Lisans tezinden özetlenmiştir.

CBu çalışma Tekirdağ Namık Kemal Üniversitesi tarafından Creative Commons Lisansı (https://creativecommons.org/licenses/by-nc/4.0/)

kapsamında yayınlanmıştır. Tekirdağ 2021
} 


\section{$\ddot{\mathbf{O} z}$}

Bu çalışmada piyasada satılan mısır ya da mısır ürünleri (mısır irmiği, mısır unu vb.) veya soya içeren işlenmiş veya yarı işlenmiş ürünler rastgele seçilerek toplamda 25 adet üründe (cips, çerez, gevrek, kuruyemiş kaplaması, un) GDO varlığı DNA temelli bir tespit metodu olan konvansiyonel Polimeraz Zincir Reaksiyonu (PCR) ile araştırılmıştır. Bu amaçla homojenize edilen örneklerde CTAB (Cetyl Trimethyl Ammonium Bromide) yöntemi ve Roche High Pure DNA Isolation Kit ile DNA izole edilerek çoğaltılması denenmiştir. DNA Isolation Kit kullanılarak DNA izole edilmesi yöntemi daha başarılı olduğundan işlemler bu yöntemle tamamlanmıştır. DNA izolasyonunun ardından Lektin geni, Zein geni, 35S Promotör ve NOS Terminatör bölgelerinin tespiti konvansiyonel PCR ile yapılmıştır. Zein geni tespiti örneklerdeki mısır varlığını, Lektin geni tespiti ise örneklerdeki soya varlığını araştırmak ve kanıtlamak amacıyla yapılmıştır. Zein ve Lektin genleri tespiti için sırasıyla GMO3/GMO4 ve Zein3/Zein4 primer çiftleri kullanılmıştır. Elde edilen DNA'ların amplifikasyonundan sonra DNA agaroz jel elektroforezi ile gözlemlenmiştir. Agaroz jel elektroforezi sonucu alınan görüntülerde 17 örnekte Lektin ya da Zein geni tespit edilirken 8 örnekte bu genler tespit edilememiştir. Lektin ya da Zein geni tespit edilen ürünlerin $35 \mathrm{~S}$ Promotör ve NOS Terminatör taraması için çalışılmaya devam edilmiştir. Bunun için sırasıyla 35S-3/35S-6 ve tNOS2F/tNOS2R primer çiftleri kullanılmıştır. Mümkün kontaminasyonları gözlemlemek için sterilize su kullanılırken, negatif kontrol amacıyla $0 \%$ Bt- 11 ve $0 \%$ GTS 40-3-2, pozitif kontrol amacıyla ise 5\% Bt-11 ve 10\% GTS-40-3-2 kullanılmıştır. 25 örneğin hiçbirinde istenen kalitede ve yeterli miktarda DNA elde edilememesinin sebebinin işleme sırasında uygulanan prosesler (kızartma, kavurma, ekstrude etme, basınç vb.) olduğu düşünülmektedir. Hiçbir numunede 35S Promotör ve NOS Terminatör bölgesine rastlanmamıştır.

Anahtar Kelimeler: GDO, Konvansiyonel PCR, Lektin geni, Zein geni, 35S Promotör, NOS Terminatör 


\section{Introduction}

Genetically Modified Organism is an organism, except for human beings, in which the genetic material has been altered in a way that does not occur naturally by mating and/or natural recombination (Kulaç et. al, 2006; Chao, 2007; Ozmert-Ergin and Yaman, 2013). The genes which are transferred to these organisms are called "transgene" (Gungoren, 2012). These genes are responsible for the genetical regulation. The two sequences more frequently used with this purpose are the promoter P-35S from Cauliflower mosaic virus (CaMV) and the nopaline synthase gene terminator, nos3', from Agrobacterium tumefaciens (McBride and Summerfelt, 1990; Jen et al., 2010; Kıran and Osmanağaoğlu, 2011). In recent years, GMOs are used in the food industry, and hence, new ideas are developed, production is growing up, and also speeded up every year. GM (Genetically Modified) agriculture was 181.5 million hectares in 2014 while it was 1,7 million hectares in 1996. So, agriculture has been a developing trend in recent years. As a result, nowadays there are many GD products. The most known are potato, tomato, rice, soybean, sunflower, peanut, rapeseed, papaya, some fish species (Kaynar, 2010).

Gene transfer is carried out by using one of biolistic, electroporation, microinjection methods, or Agrobacterium-mediated gene transfer. While producing a GM product has many benefits such as an increase in quality, production and endurance time of the product, development of new drug formula and new food types, reduction of product waste, and recycling to the environment, it also has adverse effects such as antibiotic resistance, potential toxicity, undesirable gene exchange, decrease in species richness, unfair competition (Çakar, 2010). Recent advances in genetic engineering have brought many questions especially about food safety, ecological balance protection, and socio-economic risks. Some scientific circles argue that the risks associated with the use of genetically modified organisms, which have a large share in agriculture, are not adequately and effectively investigated (Ekinci, 2008).

This study is aimed to determine whether there are genetic modifications in chips and breakfast cereals. It is tried to clarify whether the GM corn or soya which is allowed to be used only feed production is used for food production by investigating GMO presence in chips, breakfast cereals, and some dried nuts covered with soya. Besides, it is aimed to have an idea about whether sufficient amounts of DNA can be obtained as a result of the DNA extraction process which is the preliminary process for the determination of GMOs in highly processed products such as chips and crisp.

\section{Materials and Methods}

A total of 25 chips, crisps and nuts samples were used as materials. Samples containing corn and soybean consist of local samples purchased from local markets. Samples were obtained from June 2014 to June 2015, they belong to different brands and whether they contain corn or soya. The methods proposed by Kay and Paoletti (2001) were used in the sampling. The samples were ground and pulverized until they were as small as possible (Guerra, 2005). Homogeneous flours (Certified Reference Materials - CRM) containing different ratios of Genetically Modified produced by European Union Institute Materials and Measurements and European Reference Materials (IRMM, ERM) were used as reference material.

\subsection{DNA Extraction and Purification of Samples}

"Roche High Pure DNA Isolation Kit " was used for DNA extraction. $200 \mathrm{mg}$ homogenized sample which was floured was put into sterile reaction tube. $1000 \mu \mathrm{l}$ of extraction Buffer was added and mixed with the vortex. After the solutions were incubated at $80{ }^{\circ} \mathrm{C}$ for 30 minutes, they were centrifuged at $12000 \mathrm{~g}$ for 10 minutes. The supernatant was added to another 2 ml-microcentrifuge tubes which contain $400 \mu 1$ Binding Buffer. Then, $80 \mu 1$ Proteinaz K solution $(20 \mathrm{mg} / \mathrm{ml} \mathrm{ddH2O})$ was added to it and incubated at $72{ }^{\circ} \mathrm{C}$ for 10 minutes. After that $200 \mu \mathrm{l}$ isopropanol alcohol was added and mixed kindly all together. $650 \mu \mathrm{l}$ solution was taken and put into the filtered tube which is also placed in the collection tube. This volume was centrifuged at $5000 \mathrm{~g}$ for $1 \mathrm{~min} .450 \mu \mathrm{l} \mathrm{Wash}$ Buffer was added after removing the passing amount to the collection tube. Again it was centrifuged at $5000 \mathrm{~g}$ for 1 minute. This washing process repeated 2 times. Filtered tubes were centrifuged at $13000 \mathrm{~g}$ for 10 seconds to remove all the Wash Buffer. Finally, filtered tube was placed in a new 1,5ml-reaction tube and 30-100 $\mu 1$ elution Buffer was added to it at $70^{\circ} \mathrm{C}$. It is centrifuged at $5000 \mathrm{~g}$ at $15-25^{\circ} \mathrm{C}$ for 1 minute. The resulting, purified template DNA was obtained. DNA was stored at $-20^{\circ} \mathrm{C}$ for later use (Ekinci, 2008). 


\subsection{Determination of $D N A$ Concentration}

The purity control and quantification of DNA in the samples were performed by spectrophotometric method. Thermo Scientific spectrophotometer was used for this purpose. The spectrophotometer was zeroed by using the sterile water, after that; the sample DNA was diluted $1 / 10$ with sterile deionized water and placed in a bath. The purity of the sample was calculated from the A260 / A280 ratio (Altındal et al., 2017)

\subsection{Agarose Gel Electrophoresis}

Electrophoresis was performed in Thermo EC horizontal gel electrophoresis system. DNA samples were run on a $2 \%$ agarose gel electrophoresis. Then, the gel was taken to the gel documentation analysis system and examined and photographed in Gene Snap Software.

\subsection{Polymerase Chain Reaction}

Techne brand thermal cycler were used for Polymerase Chain Reaction (PCR). The reaction mixture was prepared specifically for each primer pairs. The primers and their sequences used in the PCR amplification experiments are given in Table 1.

Table 1. Primary Properties of Zein Gene, Lectin Gene, 35 S Promoter and NOS Terminator Region

\begin{tabular}{ccccc}
\hline Primer name & Target gene & $\begin{array}{c}\text { Primer } \\
\text { length (bp) }\end{array}$ & Base Sequence & $\begin{array}{c}\text { PCR product } \\
\text { length (bp) }\end{array}$ \\
\hline Zein3 & Zein & 19 & AGTGCGACCCATATTCCAG & 277 \\
Zein4 & & 21 & GACATTGTGGCATCATCATTT & 118 \\
GMO3 & Lectin & 22 & GCCCTCTACTCCACCCCCATCC & 147 \\
GMO4 & & 23 & GCCCATCTGCAAGCCTTTTTGTG & 151 \\
35S-3 & CaMV Promoter & 20 & GACAGTGGTCCCAAAGATGG & \\
35S-6 & 20 & GTCTTGCGAAGGATAGTGGG & \\
tNOS 2F & NOS Terminator & 29 & GTCTTGCGATGATTATCATATAATTCTG & \\
tNOS 2R & & 25 & CGCTATATTTTGTTTCTATCGCGT & \\
\hline
\end{tabular}

Variable contents primers, dNTPs and the amount of water are shown in Table 2 and Table 3 . The thermalcycler program reported by Horuz and Aysan (2018) was modified and used in PCR processes.The conditions for PCR amplification of CaMV 35S promoter, NOS terminator, maize-specific gene (zein) and soy-specific gene (lectin) are summarized in Table 4 and Table 5. The obtained PCR products were evaluated by agorase gel electrophoresis technique at 130 volts for 30 minutes by gel documentation analysis system (GeneGenius, Syngene).

Table 2. PCR Mix for the Detection of Zein and Lectin Gene (for 1 sample)

\begin{tabular}{lll}
\hline Content & Last Concentration & For 1 Sample $(\boldsymbol{\mu L})$ \\
\hline Steril deionized water & $1 \times$ & 16 \\
$10 \times \mathrm{PCR} \mathrm{Buffer}_{25 \mathrm{mM} \mathrm{MgCl}}$ & $2.5 \mathrm{mM}$ & 2.5 \\
$10 \mathrm{mM}$ dNTPs & $0.2 \mathrm{mM}$ & 2.5 \\
$20 \mu \mathrm{M}$ oligonucleotide ZEIN3 or GMO3 & $0.5 \mu \mathrm{M}$ & 0.5 \\
$20 \mu \mathrm{M}$ oligonucleotide ZEIN4 or GMO4 & $0.5 \mu \mathrm{M}$ & 0.625 \\
Taq DNA polymerase & $0.025 \mathrm{U} / \mu \mathrm{L}$ & 0.625 \\
gDNA(5 ng/ $\mu \mathrm{L})$ & $0.4 \mathrm{ng} / \mu \mathrm{L}$ & 0.25 \\
TOTAL & & 2 \\
\hline
\end{tabular}

Table 3. PCR Mix for the Detection of 35S Promotor and NOS Terminator Regions

\begin{tabular}{lll}
\hline Content & Last Concentration & For 1 Sample $(\boldsymbol{\mu L})$ \\
\hline Steril deionized water & & 16 \\
$10 \times$ PCR Buffer & $1 \times$ & 2.5 \\
$25 \mathrm{mM} \mathrm{MgCl}$ & $2.5 \mathrm{mM}$ & 2.5 \\
$10 \mathrm{mM} \mathrm{dNTPs}$ & $0.2 \mathrm{mM}$ & 0.5 \\
$20 \mu \mathrm{M}$ oligonucleotide & $0.5 \mu \mathrm{M}$ & 0.625 \\
$20 \mu \mathrm{M}$ oligonucleotide & $0.5 \mu \mathrm{M}$ & 0.625 \\
Taq DNA polymerase & $0.025 \mathrm{U} / \mu \mathrm{L}$ & 0.25 \\
gDNA $(5 \mathrm{ng} / \mu \mathrm{L})$ & $0.4 \mathrm{ng} / \mu \mathrm{L}$ & 2 \\
TOTAL & & $25 \mu \mathrm{L}$ \\
\hline
\end{tabular}


Table 4. PCR Program for Zein and Lectin Gene

\begin{tabular}{llll}
\hline Program & Temperature $\left({ }^{\circ} \mathrm{C}\right)$ & Time (min) & Number of Cycles \\
\hline Initial Denaturation & 95 & 3 & 1 \\
Denaturation & 96 & 1 & \\
Annealing/ Extension & 60 & 1 & 30 \\
Final Extension & 72 & 3 & 1 \\
Cooling & 4 & - & \\
\hline
\end{tabular}

Table 5. PCR Program for 35S Promoter and NOS Terminator Regions

\begin{tabular}{llll}
\hline Program & Temperature $\left({ }^{\circ} \mathrm{C}\right)$ & Time & Number of Cycles \\
\hline Initial Denaturation & 95 & $10 \mathrm{~min}$ & 1 \\
Denaturation & 95 & $15 \mathrm{~s}$ & \\
Annealing & 60 & $15 \mathrm{~s}$ & \\
Extension & 72 & $15 \mathrm{~s}$ & 35 \\
Final Extension & 72 & $7 \mathrm{~s}$ & 1 \\
Cooling & 4 & - & \\
\hline
\end{tabular}

\subsection{Detection Tests in Conventional PCR}

Studies have been conducted to detect the presence of maize and soybean by using the Zein gene and Soybean gene respectively. In order to investigate the presence of genetic modification, studies have been conducted to determine the $35 \mathrm{~S}$ promoter and NOS terminator regions.

\section{Determination of Lectin and Zein gene in conventional PCR.}

Specific primers were used to detect species-specific genes of maize and soybean. Zein3 / Zein4 primer pair was used for Zein gene detection and GMO3 / GMO4 primer pair was used for determination of Lectin gene. The expected band size for the Lectin gene is $118 \mathrm{bp}$ and $277 \mathrm{bp}$ for the Zein gene in the gel image (Turhan and Kafkas, 2013).

\section{Determination of genetically modified maize and soybean.}

DNA amplification results was evaluated on agarose gel image and samples which Zein or Lectin gene were detected were analyzed to detect if they contain $35 \mathrm{~S}$ promoter and NOS terminator regions. Detection of one of these regulatory sequences in soybean and / or maize indicates the presence of GMO (Querci et al., 2002). Primers 35S3 and 35S6 (Berben and Dardenne, 2001) were used for the detection of the 35S promoter (CaMV) region, and tNOS2F and tNOS2R (Meriç et al., 2014) for the detection of the NOS terminator region. PCR products were analyzed by $2 \%$ agarose gel electrophoresis. The results were interpreted as with / without GMO.

\section{Results and Discussion}

\subsection{DNA Isolation}

DNA extraction was carried out with both $\mathrm{CTAB}$ and commercial kit and it was observed that the kits were superior to CTAB method in terms of quantity and quality of DNA. So, DNA obtained from commercial kit was used at DNA isolation.

In many studies it is demonstrated that DNA isolation method can produce significantly different DNA yields and purity for different maize and soybean foodstuffs (Brara et al., 2020; Chakraborty et al., 2020; Stefanova et al., 2013; Turkec et al., 2015). Our observations are in accordance with previous studies, in which the commercial kits are generally considered the best for getting better results in both yield and purity for maize flour, maize starch, maize flakes (Rizzi et al., 2003; Smith and Maxwell, 2007; Peano et al., 2004). Besides, Mafra et al. (2008) studied the DNA extraction methods for soybean derived food products. They verified that the commercial kits (Nucleospin and Genespin) gave better results in both yield and purity of soybean flour and simple products than CTAB method. On the other hand, there are several studies verified that CTAB method was more effective in DNA purity and yield. Turkec et al. (2015) demonstrated that CTAB method was the most efficient method for extracting high amounts of DNA from maize bread, chips, maize-based biscuit, diet breakfast cereal, canned maize, and maize seed, compared to the commercial kits. Furthermore, at the other studies, it is verified that CTAB 

method gave better results for the extraction of DNA from raw soybean, raw maize and animal feed (Tung-Nguyen et al., 2009); other processed food matrices (CRM of Roundup Ready Soybean (RRS)) (Cankar et al., 2006); dairy foods (Pirondini et al., 2010); and soy DNA in chocolate and biscuits (Gryson et al., 2004).

\subsection{Determination of DNA Concentration}

DNA was extracted from food samples by using kit. DNA concentrations were calculated according to the results obtained from the spectrophotometric measurements (A260 / A280) of the products (Altındal et al., 2017). DNA concentrations (DNA Concentration $=\mathrm{OD}_{260} \mathrm{x}$ Coefficient (50) $\mathrm{x}$ Dilution Factor) ranged from 0.64 to 140.3 $\mathrm{ng} / \mu 1$, while DNA purity $\left(\mathrm{A}_{260} / \mathrm{A}_{280}\right)$ varied between 0.7743 and 2.088. The highest DNA amount was obtained from soybean and maize flour, while less amount and quality of DNA was obtained than corn chips, corn flakes and dried nuts with soy sauce.

Obtaining high quantity and quality of DNA depends on DNA extraction method. In addition the complexity of food matrices also affect this quality and quantity. Food matrices may contain proteins, polyphenols, and a number of PCR inhibitors such as tannins, alkaloids, polysaccharides which casuse difficulties in extraction and purification of higy-quality DNA. Foods are subjected to more than one process step including mechanical, thermal, enzymatic and chemical. This situation affects the integrity and amount of DNA obtained and may cause DNA degradation (Abdel-Latif and Osman, 2017; Fernandes et al., 2016; Mafra, 2008; Terry et al., 2002). This explains the decrease in the quality of DNA obtained with the increase of food processing steps applied to food in our study.

The integrity and quality of DNA affected by food process steps has been the subject of several studies. Mechanical processing, high temperatures and oil extraction/refining are the most studied processes (Fernandes et al., 2016). Food is subjected to a large number of different physical and chemical processes, and these processes can be applied alone or in combination. Mechanical food processes can be seperation, purification, while thermal processes are pasteurization, cooking, roasting including chemical reactions (Maillard reaction), or biochemical methods (e.g. enzymatic treatment of food) (Sathe and Sharma, 2009).

Shear forces (centrifugation, pumping, filtration) applied in mechanical processes may cause DNA degredation. Especially milling process for producig flour, grits or cornmeal which are used in bakery and extrusion products can cause DNA degredation. Chen et al. (2005) studied the effect of grinding, cooking, blending, homogenization, sterilization and spray-drying on the length of DNA fragments and they demonstrated that grinding have the greatest impact. Murray et al. (2009) also observed that DNA degradation increased in dried and blended soybeans. These data were in good agreement with work Chen et al. (2005).

Several studies showed that thermal treatment has a significant effect on the amount of DNA extracted from the food matrix, particularly on GM-derived food (Bergerova et al., 2010; Vijayakumar et al., 2009). In this studies DNA degradation was monitored by PCR. Besides, the integrity of heated DNA decreases in the duration of heat exposure. Chen et al. (2005) analyzed the changes of endogenous Lectin gene and exogenous epsps gene in transgenic raw materials and in samples from three soybean foods (bean curs, soy milk and soy powder) during eight processes (grinding, cooking, coagulation, squeeze-molding, blending, homogenization, sterilization, and spray-drying). They concluded that all processes affected the degradation of both genes in transgenic foods. They stated that heating at $100{ }^{\circ} \mathrm{C}$ for $15 \mathrm{~min}$ did not change the size of DNA fragments but, super-high-temperature and high-pressure sterilization at $121{ }^{\circ} \mathrm{C}$ for 30 resulted in large-scale degradation. Ballari and Martin (2013) investigated the effect of various processing treatment such as baking, microwaving, autoclaving, and ultraviolet irradiation on the content of MON810 maize. They demonstrated that thermal processing at $100{ }^{\circ} \mathrm{C}$ leads to significant DNA degradation. Also several studies emphasized that thermal treatment (approximately $200 / 220^{\circ} \mathrm{C}$ ) substantially reduces the size and quantity of the extracted DNA (Gryson et al., 2007, Hrncirova et al., 2008). Bauer et al. (2004) investigated the degredation of plant DNA during food processing, and they produced potato sticks, flakes and chips. The potatoes were subjected to high temperatures $\left(150\right.$ to $\left.175^{\circ} \mathrm{C}\right)$ for the short times (minutes) which conditions are commonly used in drying and frying processes. They stated that DNA strongly degraded by the heat treatment steps. Apart from that, Vijayakumar et al. (2009) concluded that, although there is a visible DNA degradation as a result of baking process, amplification was still possible.

In our study, we used maize flour, soybean, cornchips, cornflakes and dried nuts as sample. According to the results given above, it is clearly understood that food processes (grinding, heat treatments, homogenizations, 
pressure) have effects on DNA integrity and detection. According the result in our study, the inability to obtain sufficient amount and quality of DNA from processed foods may be attributed to this.

\subsection{Plant Specific PCR}

The results obtained from the PCR procedure are shown in Figure 1. According to results, 277 bp (base pairs) PCR product was obtained in C1, C2, C3,C3, C4, C5, C6, C7, C9, C10, N1, N5, N6, MF1, MF2, MF3 samples, so the Zein gene was determined. From 17 out of 25 samples, Zein or Lectin genes were obtained. Zein gene was obtained from $90 \%$ of chips products and $50 \%$ of the dried nuts samples, but no soybean gene was obtained from these samples. While no Zein gene was obtained from any of the corn flakes samples, Zein gene was obtained from $100 \%$ of corn flour and Lectin gene was obtained from $100 \%$ of soy flour.

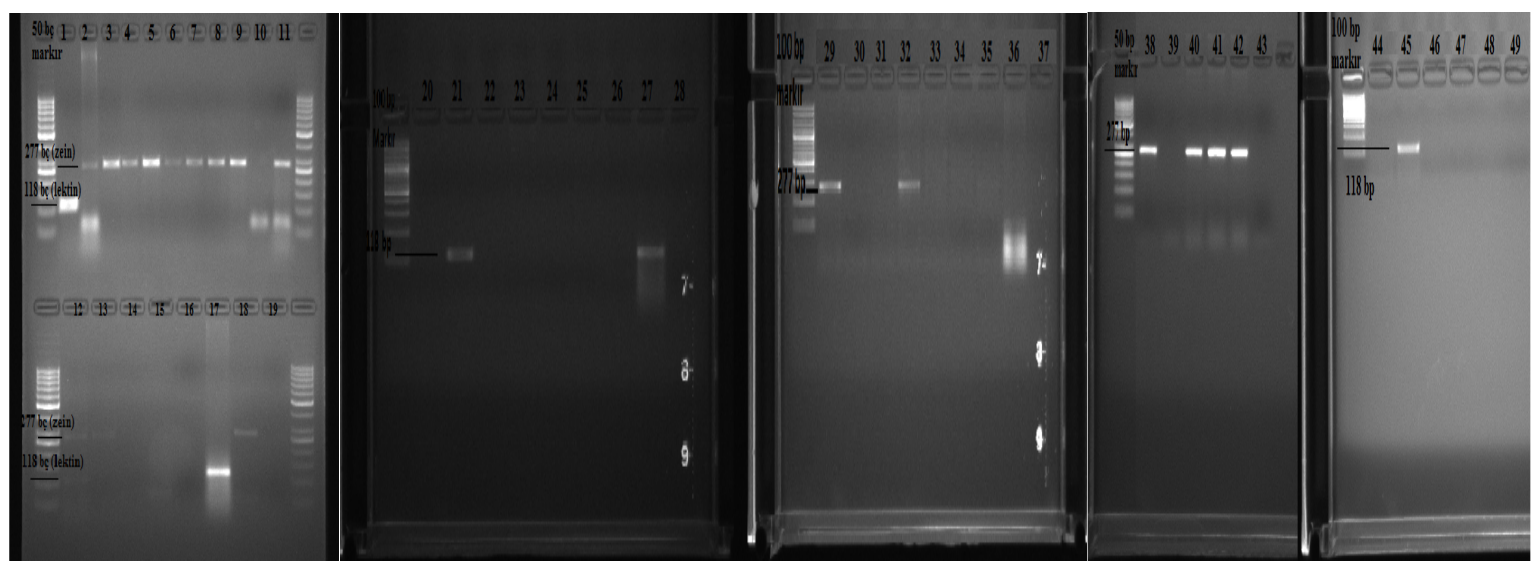

Figure 1. Searching for the Zein and Lectin Gene Using the Primer Pairs ZEIN3 / ZEIN4 for Zein and GMO3 / GMO4 for Lectin in the Samples. $1=1 P C$ (\%0 GTS 40-3-2 Soy), 2= PC (\%0 Bt-11 Maize), $3=C 1$, $4=C 2,5=C 3,6=C 4,7=C 5,8=C 6,9=C 7,10=C 8,11=C 9,12=C 10,13=N 1,14=N 2,15=N 3,16=N 4$, $17=S F 1,18=N 5,19=$ Blank, 20=NC (\%0 Bt-11 Maize), 21=PC (\%0 GTS 40-3-2 Soy), 22=CF1, 23=N5, $24=C F 2,25=C F 3,26=C F 4,27=S F 2,28=B l a n k, 29=P C(\% 0$ Bt-11 Maize $), 30=N C(\% 0$ GTS 40-3-2 Soy), 31=CF1, 32=N5, 33=CF2, 34=CF3, 35=CF4, 36=SF2, 37=Blank, 38=PC (\%0 Bt-11 Maize $)$, $39=N C(\% 0$ GTS 40-3-2 Soy), 40=MF1, 41=MF2, 42=MF3, 43=Blank, 44=NC (\%0 Bt-11 Maize), 45= $P C(\% 0$ GTS 40-3-2 Soy), 46=MF1, 47=MF 2, 48=MF 3, 49= Blank

\subsection{Investigation of 35S Promoter, NOS Terminator Presence by Conventional PCR Method}

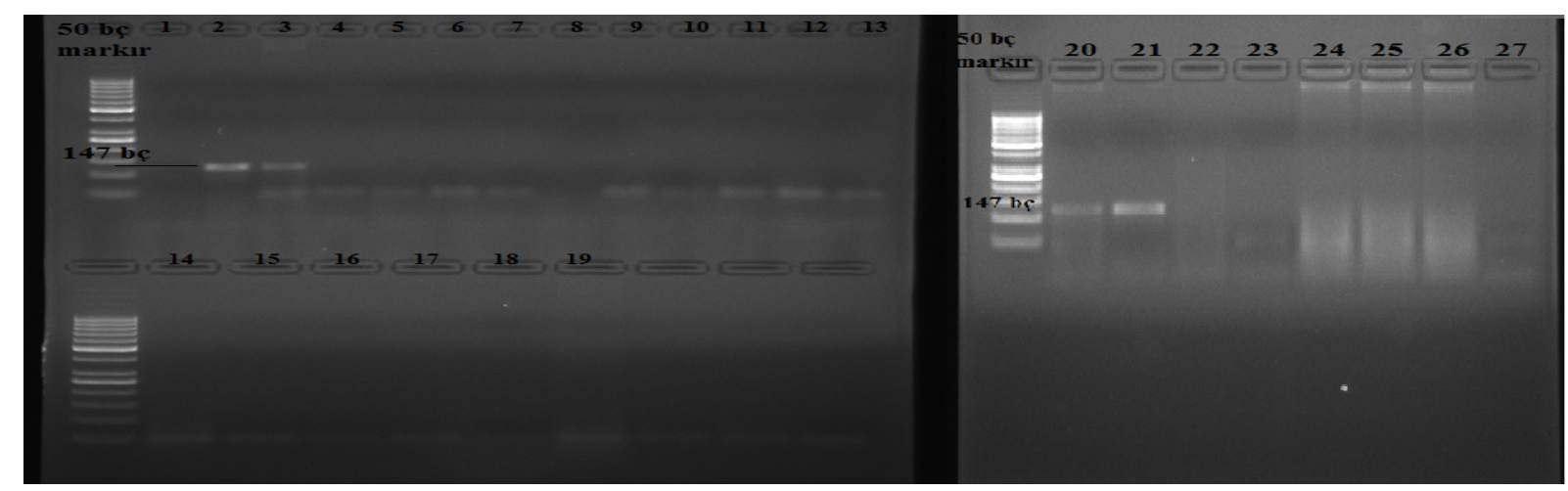

Figure 2. PCR Amplification in Maize or Soy Gene Obtained Samples by Using Primer Pair 35S-3 and 35S-6. $1=N C(\% 0 \mathrm{Bt} 11), 2=P C(\% 5 \mathrm{Bt} 11), 3=P C$ (\%1 GTS 40-3-2 Soy), 4= NC (\%0 GTS 40-3-2 Soy), 5=C1, 6=C2, $7=C 3,8=C 4,9=C 5,10=C 6,11=C 7,12=C 9,13=C 10,14=N 1,15=S F 1,16=N 5,17=S F 2,18=N 6,19=$ Blank, 20=PC (\%5 Bt 11), 21=PC (\%1 GTS 40-3-2 Soy), 22= NC(\%0 Bt 11), 23= NC (\%0 GTS 40-3-2 Soy), $24=M F 1,25=M F 2,26=M F 3,27=$ Blank

In the studies performed, 35S3 and 35S6 primers were used for determination of $35 \mathrm{~S}$ promoter region. The primers $\mathrm{tNOS} 2 \mathrm{~F}$ and $\mathrm{tNOS} 2 \mathrm{R}$ were used for the determination of the NOS terminator region (Table 1). In the experiments, 10\% GTS 40-3-2 Soybean and 5\% Bt-11 Maize standard reference materials were used as a positive control (PC), 0\% GTS 40-3-2 Soybean and 0\% Bt-11 Maize standard reference materials were used as a negative 
control (NC). Sterile deionized water (Blank) was used to detect possible contamination in the PCR mixture. These analyzes were carried out on 17 samples that could obtain Lectin or Zein genes. While the size of the detected DNA fragment by primers 35S3 and 35S6 was $147 \mathrm{bp}$, the size of the detected DNA fragment by primers tNOS2F and tNOS2R was $151 \mathrm{bp}$. According to the results shown in Figure 2 and Figure 3, all of the examples are negative for the $35 \mathrm{~S}$ promoter and NOS terminator region.

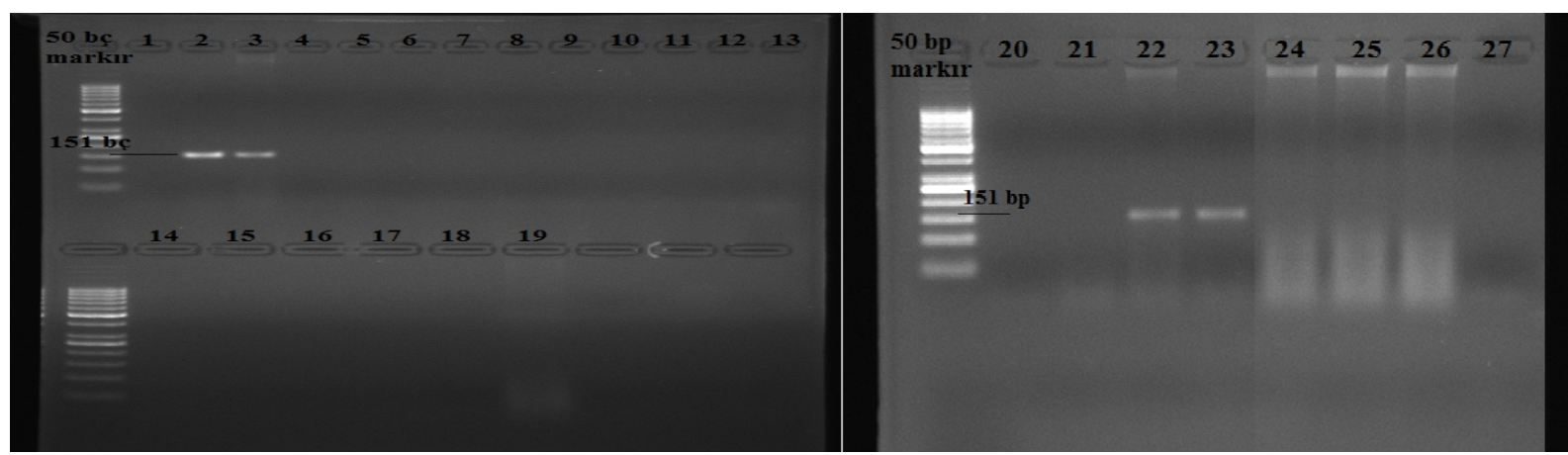

Figure 3. PCR Amplification in Maize or Soybean Gene Obtained Samples with Primer Pair tNOS2F and tNOS2R $1=N C(\% 0$ Bt 11), 2= PC(\%5 Bt 11), 3= PC (\%1 GTS 40-3-2 Soy), 4= NC (\%0 GTS 40-3-2 Soy), 5= $C 1,6=C 2,7=C 3,8=C 4,9=C 5,10=C 6,11=C 7,12=C 9,13=C 10,14=N 1,15=S F 1,16=N 5,17=S F 2$, $18=$ N6, 19= Blank, 20= NC (\%0 GTS 40-3-2 Soy), $21=N C(\% 0$ Bt 11), $22=P C(\% 5$ Bt 11), 23=PC $(\% 1$ GTS 40-3-2 Soy), 24=MF, 25=MF2, 26=MF3, 27=Blank

Turkec et al. (2015) investigated the GMO presence in 49 maize produsts (maize foodstuffs and feeds) sold in Turkish markets. According to their results, 2 samples (\%4) contained both 35S and NOS, and 9 samples (\%8) contained the presence of one GM element (NOS). They stated that 2 of the 9 samples with GM material were maize starch, one of each of diet breakfast and maize feed. Similarly, Gurakan et al (2011) investigated the presence of GM maize (Bt11) in a total of 31 foods and feeds, including a variety of highly processed maize products. They detected $35 \mathrm{~S}$ promoter in 11 out of 31 samples. Of these 11 samples, 7 samples were both $35 \mathrm{~S}$ and NOS positive. However, they stated that the highly processed products containing maize ingredients (maize starch, corn flakes, maize chips and popcorn) were neither 35S nor NOS positive. Also they remark that 3 out of 4 kernel corn and 1 out of 4 maize flour sample gave positive amplification signal for Bt11 maize. 75 soya-containing food and feed samples were screened for GMO content by qualitive and quantitative PCR by Turkec et al. (2016). While 6 out of 56 food samples (\%10.7) were found to be GM positive, 15 out of 19 feed samples were reported to be GM positive. The threshold levels of GM positive food samples were also stated to be less than \%0.9. Turkey has similar threshold limits in compliance with EU legislation. Any GM events have yet been approved for food use in Turkey. But Turkey also imports large quantities of feed, and it is stated in several studies that the presence of GM soy in feeds is highly. Studies also highlight that GM soy can be found in foods. These results given above demonstrate that maize foodstuffs and feeds sold in Turkey may contain GM material without any indications for consumers.

\section{Conclusions}

PCR is based on the amplification of genomic DNA fragments under conditions in which short oligonucleotide primers with a sequence complementing the target DNA synthesize this DNA (Çakmak, 2010). For this purpose, the analysis was completed in three steps: first isolation of DNA from the products, the detection of the presence of Zein or Lectin, and finally the detection of the GMO in the products obtained from Zein or Lectin gene.

According to the results, it was determined that chips, cornflakes, and dried nuts were not genetically modified or the amount of genetically modified DNA was below the limits that could be determined. When the production processes of the selected products except soybean and corn flour were considered, a sufficient amount and quality of DNA could not be obtained in 8 samples. The DNA structures of these products are estimated to be damaged, and it is thought that the DNA fragments to be amplified may not be of sufficient length and quality.

This may be explained by the fact that DNA may not be reproduced due to damage to the DNA due to the processes they were exposed to during the processing of the products. Temperature, low $\mathrm{pH}$, nuclease can cause hydrolysis, impurity and / or enzymatic degradation of DNA (Gachet et al., 1999; Lipp and Anklam, 2002). In 
addition, there are studies showing that the heat treatment applied to the products deteriorates the DNA and the average fragment length decreases in the majority (Meyer, 1999; Aydın, 2004).

DNA isolated from processed foods is generally of low quality and has shorter target sites (Hemmer, 1997). The efficiency of PCR depends on the quality and purity of the DNA obtained.

DNA quality can also be determined by the length of fragments and the rate of damage (Ekinci, 2008; Lipp and Anklam, 2002). As a result of frying, heating, and filtering the products, the DNA structure may deteriorate with the applied pressure or temperature (Pauli et al., 2000).

Pauli et al. (2000) listed the process steps in corn product production from many steps to fewer steps as corn grain, corn flour, popcorn, corn starch, corn chips and corn flakes. When the samples used in the study are examined; starch, corn flour and soy flour can be considered with the low process while the other samples are considered as medium or high process food according to the explanations made above. The fact that the plant gene is obtained from all corn and soy flour while the plant gene cannot be obtained in some of the chips and dried nuts and corn flakes can be explained as the reason for the decrease in the amount and quality of the DNA obtained from these samples which are considered as medium or high processed foods.

Because the Zein or Lectin gene was so worn that it could not be observed, it was not possible to obtain clear information about whether these samples contain GM as a result of not continuing forward analyses.

As a result, no foreign gene was detected in corn chips, corn flakes, popcorn, dried nuts with soy sauce and soy and corn flour.

This study draws attention to the necessity of continuing the studies for the determination of GMO type and amount of genetic modification in foods, to develop reliable, easy-to-use methods that can yield accurate results with fewer DNA isolates.

This study draws attention to the need for studies with less DNA isolates to determine GMO type and amount in the determination of genetic modification in foods by developing reliable and easy-to-use methods.

\section{Acknowledgment}

This study was financially supported by Namik Kemal University Scientific Research Projects Coordination Department, project number NKUBAP.00.24.AR.13.13. This article is produced from M.S. thesis of Şebnem Mutlu. 


\section{References}

Abdel-Latif, A., Osman, G. (2017). Comparison of three genomic DNA extraction methods to obtain high DNA quality from maize. Plant Methods, 13:1,1-9.

Altındal, D., Altındal, N., Akgün, İ. (2017). Tritikale (X Triticosecale Wittmack) genotiplerinin ISSR-PCR yöntemi ile moleküler düzeyde tanımlanması. Journal of Tekirdag Agricultural Faculty, 14 (03): 19-26.

Aydın, G. (2004). Detection and Quantification of Genetically Modified Maize Via Polymerase Chain Reaction. Msci. Thesis, Department of Biotechnology, METU, Ankara.

Ballari, R.V., Martin, A. (2013). Assessment of DNA degradation induced by thermal and UV radiation processing: Implications for quantification of genetically modified organisms. Food Chemistry, 141:2130-2136.

Bauer, T., Hammes, W.P., Haase, N.U., Hertel, C. (2004). Effect of food components and processing parameters on DNA degradation in food. Environ. Biosafety Res., 3:215-223.

Berben, G., Dardenne, P. (2001). Traçage et authentification des produits à base d'organismes génétiquement modifiés, Recherches financées par les SSTC dans le cadre du programme de "Recherche pré-nominative dans le secteur alimentaire", CRA-W, rapport finale contract $\mathrm{NP} / 42 / 026$.

Bergerova, E., Hrnčírová, Z., Stankovská, M., Lopašovská, M., Siekel, P. (2010). Effect of thermal treatment on the amplification and quantification of transgenic and non-transgenic soybean and maize DNA. Food Anal. Methods, 3: 211-218.

Brara, Z., Costa, J., Villa, C., Grazina, L., Bitam, A., Mafra, I. (2020). Surveying genetically modified maize in foods marketed in Algeria. Food Control, 109

Cankar, K., Stebih, D., Dreo, T., Zel, J., Gruden, K (2006). Critical points of DNA quantification by real-time PCR-effects of DNA extraction method and sample matrix on quantification of genetically modified organisms. BMC Biotechnol., 6:37-51.

Chakraborty, S., Saha, A., Anathram, A.N. (2020). Comparison of DNA extraction methods for non-marine molluscs: is modified CTAB DNA extraction method more efficient than DNA?. Protocols and Methods, 10:69.

Chao, E. (2007). A Risk-Based Classification Scheme for Genetically Modified Foods:Establishing Levels of Concern to Guide Testing Requirements. Faculty of Graduate and Post Doctoral Studies. University of Ottawa Canada, 19-75.

Chen, Y., Wang, Y., Ge, Y., Xu, B. (2005). Degradation of endogenous and exogenous genes of roundup-ready soybean during food processing. J. Agric. Food Chem., 53: 10239-10243.

Çakar, T. (2010). Genetiği Değiştirilmiş Organizmalar ve Tüketici Hakları. Farklı Boyutlarıyla Genetiği Değiştirilmiş Organizmalar, Ed: D. Aslan, Şengelen M., Ankara, 75-84.

Çakmak, A.I. (2010). Türkiye’ de Satışa Sunulan Bazı Gıda Ürünlerinde Genetik Modifiye Mısır Bileşenlerinin Aranması. (Master's Thesis) İstanbul Technical University, Institute of Science, İstanbul Turkey.

Ekinci, M.B. (2008). İşlenmiş ve İşlenmemiş Bazı Mısır Ürünlerinde Genetik Modifikasyonun Tespiti. (Ph.D. Thesis) Institute of Science, Ankara University, Department of Food Engineering, Ankara. Turkey.

Fernandes, T.J.R., Costa, J., Placido, A., Villa, C., Grazina, L., Meira, L., Oliveira, M.B.P.P., Mafra, I. (2016). Genetically Modified Organism Analysis as Affected by DNA Degradation, Editor: R.R. WATSON and V.R. PREEDY, Genetically Modified Organisms in Food (P. 111-118), Academic Press, Portugal.

Gachet, E., Martin, G.G., Vigneau, F., Meyer, G. (1999). Detection Of Genetically Modified Organisms (Gmos) By PCR: A Brief Review Of Methodologies Available. Trends in Food Science and Technology, 9: 380-388.

Gryson, N., Messens, K., Dewettinck, K. (2004). Evaluation and optimisation of five different extraction methods for soy DNA in chocolate and biscuits extraction of DNA as a first step in GMO analysis. J Sci Food Agric., 81:231-234.

Gryson, N., Dewettinck, K., Messens, K. (2007). Detection of genetically modified soy in doughs and cookies. Cereal Chem., 84: 109-115.

Guerra, F.X.M. (2005). Development of technique for the quantification of DNA from genetically modified organisms in processed foods. Chair of Allegement Food Technology. Münich Technical University.

Güngören, A.V. (2012). Genetiği Değiştirilmiş Tarım Ürünlerinin Türkiye Açısından Değerlendirilmesi. Master’s Thesis. Ankara University, Institute of Science, Ankara, Turkey.

Gurakan, G.C., Aydın, G., Yılmaz, R. (2011). Qualitative detection of GM maize (Bt11) in food and feed sold commercially in Turkey by PCR based methods. Indian Journal of Biotechnology, 10: 143-146.

Hemmer, W. (1997). Foods Derived From Genetically Modified Organisms And Detection Methods. http://www.bats.ch/bats/publikationen/1997-2_gmo/gmo_food.pdf (accessed date, 10.07.2015).

Horuz, S., Aysan, Y. (2018). Kabakgil tohumlarında karpuz bakteriyel fide yanıklığı ve meyve lekesi hastalığı etmeni Acidovorax citrulli'nin varlığının belirlenmesinde kullanılabilecek uygun yöntem(ler)in saptanması. Journal of Tekirdag Agricultural Faculty, 15 (03): $36-43$.

Hrncirova, Z., Bergerova, E., Siekel, P. (2008). Effects of technological treatment on DNA degradation in selected food matrices of plant origin. 
J. Food Nutr. Res., 47: 23-28.

Jen, Lu. I., Lin, C., Ming, T. (2010). Establishment Of A System Based On Universal Multiplex-PCR For Screening Genetically Modified Crops. Pan Anal Bioanal Chemistry, 396: 2055-2064.

Kay, S. and Paoletti, S. (2001). Sampling strategies for GMO detection and/or quantification. Rev 4.2, 23 Nov. 2001. EC. Directorate general JRC. IHCP (Institute for Healt and Consumer Protection). Food Products Unit: GMO: Food and Environment.

Kaynar, P. (2010). Genetik Olarak Değiştirilmiş Organizmalar (GDO)'a Genel Bir Bakış. Türk Hijyen ve Deneysel Biyoloji Dergisi. 66: 177185.

Kıran, F., Osmanağaoğlu, Ö. (2011). Gıdalarda Genetik Yapısı Değiştirilmiş Organizmaların (GDO) Belirlenmesi. Gıda, 36(5): $295-302$.

Kulaç, İ., Ağırdil, Y., Yakın, M. (2006). Sofralarımızdaki Tatlı Dert, GDO ve Halk Sağlığına Etkileri. Türk Biyokimya Dergisi., 31(3):151155 .

Lipp, M. and Anklam, E. (2002). Validation of an immunoassay for the detection and quantification of roundop-ready soybean in food and feed fraction by the use of reference materials. European Commission Joint research Centre. Institute for Healt and Consumer Protection. Food Production and Consumer Goods Unit. 260p. Ispra, Italy.

Mafra, I., Silva S.A., Moreira, E.J.M.O., Ferreira da Silva, C.S., Beatriz, M., Oliveira, P.P. (2008). Comparative study of DNA extraction methods for soybean derived food products. Food Control, 19:1183-1190.

McBride, K., Summerfelt, K. (1990). Improved Binary Vectors For Agrobacterium Mediated Plant Transformation. Plant Mol Biol, 14: 269276.

Meriç, S., Çakır, Ö., Turgut, K.N., Arı, Ş. (2014). Detection of Genetically Modified Maize And Soybean in Feed Samples. Gen. and Mol. Res. 2014; 13: 160-1168.

Meyer R (1999). Development And Application Of DNA Analytical Methods For The Detection Of Gmos in Food. Food Control, 10: 391399.

Murray, S.R., Butler, R.C., Timmerman-Vaughan, G.M. (2009). Quantitative real-time PCR assays to detect DNA degradation in soy-based food products. J. Sci. Food Agric., 89: 1137-1144.

Ozmert-Ergin, S. ve Yaman, H. (2013). Genetiği Değiştirilmiş Gıdalar ve İnsan Sağlı̆̆ı Üzerine Etkileri. Gümüşhane University, Sağlık Bilimleri Dergisi, 2(2): 261-274.

Pauli, U., Liniger, M., Zimmerman, A., Schrott, M. (2000). Extraction and amplification of DNA from 55 foodstuffs. Mitt. Lebensm. Hyg. , 91: 491-500

Peano, C., Ruijter, J.M., Deprez, R.H.L., Moorman, A.F.M. (2004). Qualitative and quantitative evalutation of the genomic DNA extract from GMO and non-GMO foodstuffs with four extraction methods. J Agric Food Chem., 52:6962-6968.

Pirondini, A., Bonas, U., Maestri, E., Visioli, G., Marmiroli, M., Marmiroli, N. (2010). Yield and amplificability of different DNA extraction procedures for traceability in the dairy food chain. Food Control., 21:663-668.

Querci, M., Van den Eede, G. and Jermini, M. (2002). The analysis of food samples for the presence of genetically modified organisms. European Commission. Joint Research Centre Manual. Bölüm 2, 5-8.

Rizzi, A., Panebianco, L., Giaccu, D., Sorlini, C., Daffonchio, D. (2003). Stability and recovery of maize DNA during food procecessing. Ital J Food Sci, 15:499-510.

Sathe, S.K., Sharma, G.M. (2009). Effects of food processing on food allergens. Mol. Nutr. Food Res., 53: $970-978$.

Smith, D.S., Maxwell, P.W. (2007). Use of quantitative PCR to evaluate several methods for extracting DNA from corn flour and cornstarch. Food Control, 18:236-242.

Stefanova, P., Taseva, M., Georgieva, T., Gotcheva, V., Angelov, A. (2013). A Modified CTAB Method for DNA Extraction from Soybean and Meat Products. Biotechnology \& Biotechnological Equipment, 27:3, 3803-3810.

Terry, C.F., Harris, N., Parkers, H.C. (2002). Detection of genetically modified crops and their derivatives: Critical steps in sample preparation and extraction. Journal of AOAC International, 85: 768-774.

Tung-Nguyen, C.T., Son, R., Raha, A.R., Lai, O.M., Clemente Michael, W.V.L. (2009). Comparison of DNA extraction efficiencies using various methods for the detection of genetically modified organisms (GMOs). Int Food Research J. , 16:21-30.

Turhan, A., Kafkas, S. (2013). Soya ve Mısırda Genetiği Değiştirilmiş Ürünlerin Belirlenmesi. Çanakkale University, Fen ve Mühendislik Bilimleri Dergisi, 29(2): 80-89.

Turkec, A., Kazan, H., Karacanli, B., Lucas, S.J. (2015). DNA extraction techniques compared for accurate detection of genetically modified organisms (GMOs) in maize food and feed products. J Food Sci Technol, 52(8):5164-5171.

Turkec, A., Lucas, S.J., Karlik, E. (2016). Monitoring the prevalence of genetically modified (GM) soybean in Turkish food and feed products. Food Control, 59: 766-772.

Vijayakumar, K.R., Martin, A., Gowda, L.R., Prakash, V. (2009). Detection of genetically modified soya and maize: impact of heat processing. Food Chem., 117: 514-521. 